DOI: $10.20472 / \mathrm{TE} .2020 .8 .1 .004$

\title{
DISCURSIVE PRACTICES OF GENDER AND TEACHING: A CASE STUDY FROM GREECE
}

\section{EMMY PAPANASTASIOU}

\begin{abstract}
:
The paper discusses how a primary education teacher who identified himself as gay, enacts, resists and reproduces dominant understandings of gender and sexuality in terms of his own identity and practice in Greece, which is a very conservative and, sometimes, hostile country towards those who do not conform to heteronormativity. The discussion is based on a social constructionist analysis of a semi-structured interview. It provides the readers with interesting stimulating data and can be the starting point of an interesting conversation about the potential struggles that LGTBIQ+ teachers and LGTBIQ+ people in general face in Greece. It is part of a larger research project regarding gender and educational leadership in Greece.
\end{abstract}

\section{Keywords:}

teachers, education, sexuality, Greece

JEL Classification: 129

\section{Authors:}

EMMY PAPANASTASIOU, Democritus University of Thrace, Komotini, Greece, Email: emmypapan@gmail.com

\section{Citation:}

EMMY PAPANASTASIOU (2020). Discursive Practices of Gender and Teaching: A Case Study from Greece. International Journal of Teaching and Education, Vol. VIII(1), pp. 47-63.,

10.20472/TE.2020.8.1.004 


\section{Introduction}

Although in Western countries there is some literature that explores the lives of LGTB ${ }^{1}$ teachers (i.e. Gray (2013) and Epstein and Johnson (1998) in the UK, Neary (2013) and (2017) in Ireland, Ferfolja and Hopkins (2013) and Ferfolja and Stavrou (2015) in Australia, Rush et al (2002), Griffinn (1992) and Harbeck (1992) in the US, Khayatt (1992) in Canada), similar research in Greece is limited. This paper adds to the limited body of literature regarding homosexuality and teachers in Greece and it is part of a larger research about gender constructions and educational leadership in Greek primary schools and draws on the speech of a teacher who self-identified as gay. A social constructionist feminist theoretical framework underpins this research.

It is based on a case study approach, as it provides to the readers data that will stimulate their interest and they will be able to draw their own conclusions (State 2005). Also, as Hardie (2012) argues 'it contributes to a wider and experiential knowledge base' (p. 274).

So, the findings of this study can be a starting point of a conversation about the potential struggles that LGTBIQ+ teachers in Greece may face and it may also lead to further research within a more representative sample in order to have results that can lead to further conclusions.

The following outline of the sections is intended to help the reader navigate their way through the paper. In the next section the notion of heteronormativity, which is the prevalent culture in Greek schools, is explained. The theoretical and empirical work that contributes to an understanding of sexuality and education follows. And then the Greek context is presented. Theoretical and methodological issues are the foci of the next sections, followed by a description of the case study teacher. The next section constitutes the analysis of my data. I conclude this paper with an overview of the key findings and contributions to knowledge and propose directions for future research.

\section{Heteronormativity}

This paper discusses perspectives of heteronormativity, which is often perceived as invisible yet it is present in all aspects of social life.

\footnotetext{
1 Throughout the text terminology is not consistent, but it follows the terminology used by each referenced researcher. As far as the researcher of this paper is concerned the term LGTBIQ+ is used.
} 
'Heteronormativity' as a concept was first described by Warner in 1993 when he used this term in his critique of mainstream social theory for being one-sided and for supporting heterosexual culture.

Berlant and Warner (1998) offered a more comprehensive definition of the concept of 'heteronormativity'. They described it as:

By heteronormativity we mean the institutions, structures of understanding and practical orientations that make heterosexuality seem not only coherent - that is, organised as a sexuality - but also privileged. Its coherence is always provisional, and its privilege can take several (sometimes contradictory) forms: unmarked, as the basic idiom of the personal and the social; or marked as a natural state; or projected as an ideal or moral accomplishment. It consists less of norms that could be summarised as a body of doctrine that of a sense of rightness produced in contradictory manifestations. Contexts that have little visible relation to sex practice, such as life narrative and generational identity, can be heteronormative in this sense, while in other contexts form of sex between men and women might not be heteronormative. Heteronormativity is thus a concept distinct from heterosexuality. One of the most conspicuous differences is that it has no parallel, unlike heterosexuality, which organises homosexuality as its opposite. Because homosexuality can never have the invisible, tacit, society-founding rightness that heterosexuality has, it would not be possible to talk of 'homonormativity' in the same sense. (p. 548)

This definition reveals how heterosexuality is privileged and supported by institutions, such as religion, education and politics. And, as I will show further along in this paper, in Greece heterosexuality is considered hegemonic through a process of normalisation and it is taken for granted in society in general and in schools in particular. Anything else than heteronormativity is considered abnormal and possibly dangerous and something that must be changed or vanished.

\section{Sexuality and education}

Although the research on the experiences of LGTBIQ+ teachers is limited (Duke 2008, Neary 2013 , 2017), there is a small but growing body of literature concerned with LGTBIQ+ teachers' experiences. So, in the US the research had mainly focused on how LGB teachers negotiate their identity in the school context (Griffin 1992). Other research in Canada and in the UK has been about the complexity of being an LGB teacher because teachers are considered as 'models for the ideological values they represent' (Khayatt 1992, p. 146) and the 'risky 
business of choosing visibility' (Grace and Benson 2000, p. 90), because they should be living 'exemplary' lives (Epstein and Johnson 1998, p. 123).

Sexuality has always been in an 'uncomfortable relationship' with schooling (Youdell 2005, p. 251). Schools are places that can be considered as unique places where the public and private spheres meet and being a teacher involves negotiating personal and professional identities (Nias 1996). This negotiation is particularly challenging for LGTB-Q teachers (Neary 2017) as they have to negotiate struggles with the heteronormative public/private spheres that dominate schools and their personal/professional identities (Gray 2013).

Sexuality is a social construct and as such it is not merely a natural drive or orientation but a cultural product that draws on any given historical time. Contemporary constructions for the LGTBIQ+ identity place sexual identity in the centre of someone's identities, as maybe the most important and essential component of the self (Connell 2015a). According to this construction, coming out is very important. But traditional constructions about the teacher expect them to be sexually neutral and perform a gender-normative self in the classroom and elsewhere (Connel 2015b, 2015c) as children are presumed innocent and unawakened to sexual and gendered knowledge (Epstein and Johnson 1998). Furthermore, regarding sexual identity the social context can play an important role to whether LGTBIQ+ people disclose (or not) their sexual identity in the workplace. A point that Jenkins (2008) clearly notes:

It is one thing to be a gay television producer, another to be a gay doctor and quite another to be a gay clergyman. Being gay in London, with a flourishing and supportive gay scene, is likely to be quite different to being gay in say, a rural village in Norfolk. (Jenkins, 2008, p. 102)

Jenings (1994) also points out that in a homophobic society 'a gay teacher is problematic' ( $p$. 14) because teachers are expected to pass along to students society's dominant values. This in Greece, as almost everywhere else in the world, may mean the traditional values of the heterosexual family and society, where the man/father is the breadwinner and the woman/mother has the caring responsibilities for the family and where there is a clear distinction between men and women. So, a gay or lesbian teacher is an oxymoron in a heteronormative society (Harbeck 1997).

Heteronormativity is constructed as natural, normal, fixed and as the only acceptable form of sexuality in schools (Epstein and Johnson 1998). The assumption that a teacher is heterosexual is almost always present in schools (Neary 2017) and this may be a source of stress for the teachers who do not conform to heteronormativity (Ferfolja 2009, Neary 2013, 
AUTHOR 2016). As King (2004) argues, 'gay' is created as the Other. So, in order to avoid being labelled as the 'Other' within the heteronormative space of school (Ferfolja 1998) and pose as a potential danger, as LGTBIQ+ teachers are usually undesirable because it is assumed that they will influence or even recruit their students (King 2004), many LGTBIQ+ teachers decide to keep silent about their sexuality. The assumption that schools are heteronormative environments has created a school climate where the teachers who draw on a non-heteronormative identity usually have either made themselves invisible through silence or have been made visible by being constructed by policies as 'wounded' who need 'protection' and a 'safe' place (Youdelll, 2004).

\section{The Greek context}

The political, cultural and religious discourse in Greece is quite hostile to LGTBIQ+. Greece is considered a conservative country where being a gay or a lesbian is regarded as a taboo issue (Eurobarometer 2007) and non-heterosexual people as an invisible group (Giannelos 2000). The Greek Orthodox Church, a major and influential institution in the country, considers homosexuality to be a sin and those with homosexual orientations as sinful. Similarly, several high-profile politicians have openly expressed disdain towards homosexual people and the media often promotes an image of exaggerated and ridiculous homosexual characters or even censor homosexual scenes in primetime series (e.g. a kiss between men shown in the British TV series 'Downton Abbey' and kisses between men and women shown in the American sitcom 'Two and a Half Men'). Unlike other European Union countries, same-sex registered partnerships did not exist in Greece until December 2015 and the legal status (cohabitation pact) of same-sex unions was not recognised. Moreover, Greek law did not recognise samesex spouses even if they hold a valid certificate from another European member state (De Shutter 2008). Qualitative research findings suggest that the population in general holds a rather negative picture of homosexuals and believes that homosexuality poses a danger to society (Tzamalouka 2000). Even many social work students in a study of their perceptions appear to have negative views of homosexuality and admit that they would not treat a person who is gay/lesbian as they would treat heterosexuals (Papadaki and Papadaki 2011, Papadaki et al 2013). Homosexual populations in Greece are stigmatised, marginalised and often subject to homophobic behaviour (Tzamalouka 2002). Recently, an MP from the far right political party of the Golden Dawn denounced homosexuality as 'sickness' (The Guardian 16/4/2014) and more recently (June 2017) a university professor of pathology during an open discussion at a public speech he gave denounced homosexuality as sickness.

Furthermore, as the Greek National Committee for Human Rights (NCHR) puts it in Greek society, the apparent tolerance towards homosexuality - especially true for the art sector, 
considered as an area where creativity and 'liberality' rightfully coexist - hides a harsh collective attitude that comes forth as soon as homosexuality is connected to people representing in some way role models to the society (i.e. politicians, teachers etc) (National commission for human rights 2008). Also, the Racist Violence Recording Network reported a spike in hate crime in Greece in 2015, with 185 out of 273 incidents of hate crime reported, having LGTBQI people targeted (Racist Violence Recording Network 2016). On October 2017 the Greek parliament approved a law allowing legal gender change. This caused a fierce condemnation by the Church and the clergymen threatened to excommunicate transgender people who are considered as 'immoral', 'disordered' and 'destroyed' (the Guardian 10/10/2017).

As argued before, schools are predominantly heteronormative institutions (Dupper and MayerAdams 2002, van Dijk and van Driel 2007) not only amongst students but also amongst teachers. It is considered normal to be heterosexual within the school environment and those who fail to be or to show their heteronormativity are at a disadvantage. So, homosexual teachers may sometimes hide or deny their identity in an attempt not to challenge the 'hegemonic machismo' (Nixon and Givens 2004, p. 2) which dominates the school system, both overtly and covertly, influencing the culture of the school system. This culture dictates expected expressions of 'masculinity' and 'femininity' and deviations for both sexes are considered as examples of 'distorted sexuality'. Similarly, Ferfolja and Hopkins (2013) argue that LGTB teachers may feel the need to hide their identity in the fear of 'discrimination, dismissal, school and/or broader community rejection, and limitations on career options and trajectories' (p. 312).

In Greece, although official data is not recorded, Pavlou (2009) refers to a report from LGTBIQ+ organisations that the outing of LGTB identity of teachers results in their dismissal from work or change of schools. He mentions an incident reported by LGTB activists that in 2007 a math teacher was allegedly sent away from school because he was seen at a gay meeting place at a park.

\section{The present study}

The present discussion draws on feminist social constructionism in its analysis of the story of a gay Greek teacher. Social constructionism was primarily selected as a theoretical framework because it enables a better understanding of the link between broad social norms and assumptions and the way people interact with each other. Social constructionism rejects the idea of an objective external reality and instead understands reality as a dynamic construction 
through people's interactions and especially through the language they use (Gubrium and Holstein 2008, Burr 2003).

In order to understand the social construction of gender, feminist research seeks to conceptualise gender as a means of control through which the subordination of those who are not powerful is made possible. Feminism is in addition linked to action and strives to improve the lived reality of those who are oppressed and change entrenched patriarchal gender relations (Papanastasiou 2016, Gergen and Davis 1997).

So, this paper is primarily concerned with examining how certain gender constructions draw upon dominant positions and how these relate to wider relations of power. Feminist social constructionism is deeply concerned with social constructions that appear in the form of concepts, practices, entities, and attributes that may constitute oppression (Friedman 2006).

I believe that gender is conceptualised neither as something individuals are born with nor acquired solely through socialisation, but as an active accomplishment that is done differently within specific social and cultural contexts (Francis 2010, Connell 2002, Messerschmidt 2011, West and Zimmerman 1987). Despite the dynamic and constantly changing gender construction, individuals are not entirely free to construct their gender identity, but they are restricted by social institutions which prescribe particular references of gender in specific contexts.

\section{Methodology}

The data presented and discussed here is based on the story of one Greek teacher, who identified himself as gay. It is part of a larger research project about the phenomenon of women's relatively low participation in educational leadership in Greek primary schools and the constructions of women and men head teachers and teachers regarding headship and gender.

Semi-structured interviews were used as this method provided the opportunity to ensure depth in the investigation of the participants' experience. It was about getting 'people to explain their answers at length' (Drever 1997, p. 6) and drawing on these statements to identify common features and differing views across the interviews. In undertaking 'semi-structured' interviews all participants answered broadly the same questions, which allowed for comparisons across interviews and facilitated data organisation and analysis (Cohen et al 2013).

In undertaking semi-structured interviews I was aiming to create a space where the respondents could engage in a dialogic process and feel more at ease and less mechanical in 
their relationship with me as the researcher (Denzin and Lincoln 2005, Oakley 1981, Rubin and Rubin 1995, Bechhofer and Paterson 2000).

The interviews were conducted in Greek, because if the respondents are able to speak in their own language, they can express themselves in a more precise way, the answers are richer and the respondents feel more relaxed (Bryman and Bell 2007). Then the interviews were translated verbatim in English. To protect the anonymity of the participants, pseudonyms are used. Informed consent was obtained from all individuals who participated in this study.

I chose to present the constructions of a particular teacher using a case study approach, as 'the case study offers the opportunity to study [...] social mysteries [...] it requires one person [...] to perform the necessary observations and interpretation of data' (Feagin et al 1991). The case study approach allow us to experience unique individuals and situations within a known culture (Rolfe 2006) and it seems from the main study (AUTHOR 2016) and from other studies (Taki 2009) that in Greek education coming out as non heteronormative is not a common thing. So, the case of this particular teacher, who came out during the interview, is a unique interesting case and should be presented.

\subsection{Case study teacher and the research procedure}

This paper discusses the account of a man teacher, who identified himself as gay, Petros. His gender identity and his constructions about school leadership are explored in-depth in this study. $\mathrm{He}$ is in his mid-thirties and has a little bit over ten years of teaching experience at several areas in Greece and at several schools, urban and rural. At the time of the research he was teaching at a rural school in a village which is situated in the North of the country. Also, it should be noted that Petros has the legal requirements in order to be a head teacher, that is 10 years of teaching experience. In addition to this, he holds a master degree on teaching, and has attended several seminars on teaching, psychology and management.

He was interviewed in 2010, at the school he was working at the time, in the office of the head teacher, where we could be alone and where it was quiet. The interview took place in the head's office, without the presence of the head, because in the teachers' office there were a lot of people (other teachers, students, parents) and along with the issue of noise, there could also be an issue of confidentiality and of Petros expressing himself openly.

The remainder of this paper focuses upon the experiences of Petros as a gay teacher in a Greek primary school. 


\section{Findings and discussion}

Teachers who are LGTBIQ+ have to make a personal decision about whether to 'come out' or not. Grace and Benson (2000) argue that this is 'a risky business' (p. 90). Petros decided to come out as gay only to a few good friends and his family and not at his school or colleagues. The dilemma he might have had to face is described by Gust (2007) who wrote: 'The choice of a teacher to be "out" in the classroom is perhaps unadvisable, possible joyous, potentially disastrous, positively political, and just plain hard' (p. 43).

As far as Petros is concerned, he said:

I have to work on being accepted as a teacher and as a person. I try not to provoke anyone. I behave as normal as I can, as 'manly' as I can. I don't know...I feel it in the air that they would rather not have me around here, but I don't give up! I am here to stay! Whether you like it or not, I am a teacher, I am a good teacher I think, and my sexual orientation is nobody's business. I am not a gay teacher, but I am a teacher who happens to be gay. But it causes problems...

At the time of the interview, his colleagues at the school had figured out his sexuality and, as he was guessing, not all of them were OK with it. He suggested that the information about his sexuality has been passed on through 'word of mouth', suggesting that a school can be what Foucault (1995) calls an 'observation machine' (p. 173) as when something is spoken or assumed (especially if this is someone's sexuality) it becomes public property. Also his opinion that he may be criticised for his work based on his sexual identity, is in line with Edo et al (2010) who found that teachers who disclosed the identity to others were viewed differently, as sexuality became the identity that defined them, exceeding other identities.

The conflicting sentence 'I am not a gay teacher, but I am a teacher who happens to be gay' may show that Petros is ambivalent about his sexual and professional identity. He seems to try to distant himself from the label he himself used before, insisting that his professional identity is separate and more important than his sexual identity. Neary (2013) argues that 'LGTBQI teachers engage with processes of resistance at different levels as they negotiate their identity positions within the school' (p. 596). Petros in this research draws upon 'particular positions for [himself]' (Mills 1997, p. 1) and resists by managing his identities (Ferfolja 2007) and by avoiding to come out. Maybe he is afraid that if he comes out as a gay person he will be assigned all that constitutes the label in the Greek society and his act of disclosure will be just limiting and not 'both liberating and limiting at the same time' as it is suggested by Neary (2013). 
From Petros words it can be assumed that in a pervasive culture of heterosexism, heterosexuality is taken for granted as normal, natural and proper. But, individuals who resist this norm, can create new identities and ways of knowing, i.e. Petros draws on being a teacher as a professional, 'a good teacher', as he says.

Similarly, Ferfolja (2007) in a study in Australia note that those who do not follow the 'acceptable' standards of (hetero)normativity in a school, may be 'punished' through overt or covert harassment, stigmatisation, ostracism and exclusion. So, as a consequence many gay teachers in Australia choose silence, because their sexuality may be considered an 'illegitimate' discourse and practice as the prevailing dominant discourse normalises heterosexuality.

Gray (2013) interviewed 20 teachers in the UK and aimed at illustrating the complexities of the coming out process. She noted that some of her participants also chose not to come out within their professional lives. The reasons for their choice were multiple and 'were related to school location and participants' understandings of the communities that surrounded their workplaces as being socially conservative' (p. 5). As it is with Petros, the participants in Gray's research felt that school's pervasive heteronormative culture involved a risk, that sometimes it was too great to take.

Petros describes his behaviour as trying to be 'manly', reflecting the 'normal', hegemonic form of (hetero)sexuality and the dominant form of gendered social relations that are constructed in an institution like a school.

When I asked him if he was thinking of applying for a headship in the future, he said:

'[My sexuality] it will cause more problems if I dare apply!'

He believes that his gay identity may disrupt his career progress as Boatwright et al (1996) explain in their study. So this highlights not only the fact that the head teacher is constructed as 'masculine', but also as heterosexual, as Kanter (1977) suggested. Blount (2003) in his study in the US context suggests that there is understandable reluctance on the part of gay (or lesbian) administrators to identify themselves given societal bias. Petros is brave enough to identify himself in the interview but, as it appears from his account, not at school. He seems to believe that by breaking the code of silence through disclosure he will not perceive less heterosexist bias but would have to deal with a lot more and this could be costly. So, he is trying not to draw attention to his identity but this consumes much of his time to hide his identity and he places himself outside the regular channels for advancement. But Petros does not reject headship at all. He considers it for the future, after he has been accepted as gay. 
Later on he adds:

I don't know how they will react if I, or somebody else who is gay, apply. I guess I will have a problem, as I am not the typical man who goes around giving orders. I am more approachable and cool with everybody.

Here Petros challenges dominant constructions of 'masculinity' as someone 'who goes around giving orders'. He presents himself as more approachable and democratic and constructs a different/alternative 'masculinity'. He chooses not to conform, but rather challenges the prevailing constructions of 'masculinity' and femininity' (i.e. being assertive like a 'typical' man). Reay and Ball (2000, p. 149) draw on Ganderton (1991) and Gunter (1997) to suggest that those who 'challenge organizational views, including orthodoxies around the 'best way to manage' are unlikely to be promoted to the position of head teacher and this seems to apply to Petros. Although he chooses in the interview not to remain silent about his sexuality, he is silent in the school context as indicated earlier. His reaction seems to confirm what Reay and Ball (2000) note, that 'the powerful in society, regardless of their sex, share more in common with each other than they share with relatively powerless members of either sex' (p. 150).

\section{Conclusion}

This paper set out to discuss a teacher's account on negotiating his private and professional life. The paper has shown that coming out in a heteronormative society can be very challenging for Petros.

Sexuality has been, and still is, critical in Western societies. The hegemony and power associated with heterosexuality means that subjectivities are regulated by heteronormative regime. In this paper I discussed the accounts of Petros, a Greek teacher who self-identified us gay during the research, but decides not to come out at school. His testimony paints a vivid and detailed account of the challenges he may have to face as he does not fit the heteronormativity of the Greek society and of the school. His words provide evidence about how he enacts, resists and even reproduces dominant understandings of gender and sexuality in terms of his own identities and practices in the school context. Regarding leadership I have offered a discussion of the possibilities, challenges and the resistances that may exist for a Greek gay teacher who may aspire for headship.

There is certainly a need for change in society's understandings and constructions around alternatives to heteronormativity, restructuring of the understandings of queer identity and reeducation of school communities that will help change assumptions about LGBTIQ+ and re- 
construct the dangerous stereotypes and misinterpretations that form the base of the heteronormative culture.

Until then LGTBIQ+ in Greece, and possibly elsewhere as well, will be 'neither us nor clearly them, not friend and not enemy, but a figure of ambivalence who troubles the border between us and them' (Phelan 2001, p. 4-5). And Petros will be pressed into the closet if heteronormative stereotypes and prejudices go unchallenged as homosexuals must remain unseen and unheard.

And as Rockhill (1993) argues:

Everytime we interrupt, speak defiantly, and/or name our difference, we risk the loss of our community, home and friends. So too in the classroom (and in the whole school I may add) difference is spoken at great risk (p. 356)

And Petros chooses not to risk, which is understandable in the Greek society of today.

In conclusion, this paper addresses the gap that exists in the literature around the experiences of gay teachers in Greece and offers the scope for further research, analysis and investigation both within the Greek context and internationally.

\section{References}

Bechhofer, F. and Paterson, L. (2000) Principles of research design in the social sciences. London: Routledge

Berlant, L. and Warner, M. (1998) Sex in public. Critical inquiry, 24, pp. 547-566. https://doi.org/10.1086/448884

Blount, J. M. (2003) Homosexuality and the school superintendents: A brief history. Journal of school leadership, 13(1), pp 7-26. https://doi.org/10.1177/105268460301300102

Boatwright, K., Gilbert, M., Forrest, L. and Ketzenberger, K. (1996) Impact of identity development upon career trajectory: Listening to the voices of lesbian women. Journal of Vocational Behavior, 48, pp. 210-228. https://doi.org/10.1006/jvbe.1996.0019

Bryman, A. and Bell, E. (2007) Business research methods. Oxford: Oxford University Press

Burr, V. (2003) The social constructionism. Hove: Routledge. https://doi.org/10.4324/9780203694992 
Cohen, L., Manion, L. and Morrison, K. (2013) Research methods in education. London: Routledge

Connell, C. (2015a) School's out: Gay and lesbian teachers in the classroom. Oakland: University of California Press

Connell, C. (2015b) Pride and prejudice and professionalism. Contexts, 14(4), pp. 32-37. https://doi.org/10.1177/1536504215611898

Connell, C. (2015c) The experiences of lesbian and gay teachers. In F. Colgan and N. Rumens (eds) Sexual orientation at work: Contemporary issues and perspectives. New York: Routledge, pp. 4357

Connell, R. W. (2002) Gender. Cambridge: Polity Press

De Shutter, O. (2008) Homophobia and discrimination on grounds of sexual orientation in the EU member states, part I- Legal analysis. Vienna: European Agency for Foundational Rights

Denzin, N. K. and Lincoln, Y. S. (eds) (2005) The SAGE handbook of qualitative research. Thousand Oaks: SAGE

Drever, E. (1997) Using semi-structured interviews in small-scale research: A teacher's guide. Glasgow: Scottish Council of Research in Education

Duke, T. S. (2008) Hidden, invisible, marginalized, ignored: A critical review of the professional and empirical literature (or lack of thereof) on gay and lesbian teachers in the United States. Journal of gay and lesbian issues in education, 4(4), pp. 19-38. https://doi.org/10.1300/J367v04n04_03

Dupper, D. R. and Meyer-Adams, N. (2002) Low-level violence: A neglected aspect of school culture. Urban Education, 37, pp. 350-364. https://doi.org/10.1177/00485902037003003

Endo, H., Reece-Miller, P. C. and Santavicca, N. (2010) Surviving in the trenches: A narrative inquiry into queer teachers' experiences and identity. Teaching and teacher education, 26(4), pp. 10231030. https://doi.org/10.1016/j.tate.2009.10.045

Epstein, D. and Johnson, R. (1998) Schooling sexualities. Buckingham: Open University Press

Eurobarometer (2007) Discrimination in EU- Summary 2007. Special Eurobarometer 263/Wave 65.4 TNS Opinion and social, European Commission. Accessed from http://ec.europa.eu/public opinion/archives/ebs/ebs 263 sum en.pdf on 18/12/2013

Feagin, J. R., Orum, A. M. and Sjoberg, G. (1991) The nature of case study. In J. R. Feagin, A. M. Orum and G. Sjoberg (eds) A case for the case study. Chapel Hill: The university of North Carolina Press 
Ferfolja T. (1998) Australian lesbian teachers: A reflection of homophobic harassment of high school teachers in New South Wales government schools. Gender and education, 10(4), pp. 401-415. https://doi.org/10.1080/09540259820835

Ferfolja T. and Stavrou, E (2015) Workplace experiences of Australian lesbian and gay teachers: Findings from a national survey. Canadian journal of educational administration and policy, 173, pp. $113-138$

Ferfolja, T. (2007) Teacher negotiations of sexual subjectivities. Gender and Education, 19(5), pp. 569586. https://doi.org/10.1080/09540250701535584

Ferfolja, T. and Hopkins, L. (2013) The complexities of workplace experience for lesbian and gay teachers. Critical studies in education, 54(3), pp. 311-324. https://doi.org/10.1080/17508487.2013.794743

Foucault, M. (1995) Discipline and punish: The birth of the prison. New York: Vintage books

Francis, B. (2010) Re/theorising gender: female masculinity and male femininity in the classroom? Gender and education, 22(5), pp. 477-490. https://doi.org/10.1080/09540250903341146

Friedman, N. (2006) Nancy J. Hirschman on the social construction of women's freedom. Hypatia, 21(4), pp. 182-191. https://doi.org/10.1111/j.1527-2001.2006.tb01135.x

Ganderton, P. S. (1991) Subversion and the organisation: Some theoretical considerations. Educational management and administration, 19(1), pp 30-36. https://doi.org/10.1177/174114329101900104

Gergen, M. M., and Davis, S. N. (1997) Toward a new psychology of gender: Opening conversations. In M. M. Gergen, and S. N. Davis (eds.) Toward a new psychology of gender: A Reader. New York: Routledge, pp. 1-27

Giannelos, G. (2000) Statement. In Th. Papazizi, N. Chatzitrifon and Th. Ktenidis (eds) Gender and behaviour, homosexuality-homophobia. The situation in Greece and perspectives for improvement. 9- 10 October, Thessaloniki. Conference Preceedings. Athens: Epikentro, pp. 1-10 [in Greek]

Grace, A. P. and Benson, F. J. (2000) Using autobiographical queer life narratives of teachers to connect personal, political and pedagogical spaces. International journal of inclusive education, 4(2), pp. 89-109. https://doi.org/10.1080/136031100284830

Gray, M. E. (2013) Coming out as lesbian, gay or bisexual teacher: negotiating private and professional worlds. Sex education, 13(6), pp. 702-714. https://doi.org/10.1080/14681811.2013.807789 
Griffin, P. (1992) From hiding out to coming out: Empowering gay and lesbian educators. In K. M. Harbeck (ed) Coming out of the classroom closet. New York: Harrington Park Press, pp. 167196. https://doi.org/10.1300/J082v22n03_07

Gubrium, J. F. and Holstein, J. A. (2008) Constructionist mosaic. In J. A. Holstein and J. F. Gubrium (eds) Handbook of constructionist research. New York: The Guilforf Press, pp. 3-10

Gunter, H. (1997) Rethinking education: The consequences of Jurassic management. London: Cassell

Gust, A. Y. (2003) The violence of heteronormativity in communication studies. Journal of homosexuality, 45(2-4) pp. 11-59. https://doi.org/10.1300/J082v45n02_02

Harbeck, K. (1997) Gay and lesbian educators: Personal freedoms, public constraints. Malder Massachusetts: Amethyst

Harbeck, K. M. (ed) (1992) Coming out of the classroom closet: gay and lesbian students, teachers, and curricula. New York: Harrington Park

Hardie, A. (2012) Lesbian teachers and students: Issues and dilemmas of being 'out' in primary school. Sex education, 12(3), pp. 273-282

Jenkins, R. (2008) Social identity. London: Routledge

Jennings, K. (1994) One teacher in ten. Boston: Alyson

Kanter, R.M. (1977) Men and women of the corporation. New York: Basic Books

Khayatt, M. D. (1992) Lesbian teachers: An invisible presence. Albany: State University of New York Press

King. J. R. (2004) The (im)possibility of gay teachers for young children. Theory into practice, 43(2), pp. 122-127. https://doi.org/10.1207/s15430421tip4302_5

Messerschmidt, J. W. (2011) The struggle for heterofeminine recognition: Bullying, embodiment, and reactive sexual offending by adolescent girls. Feminist criminology, 6(3), pp. 203-233. https://doi.org/10.1177/1557085111408062

Mills, S. (2007) Discourse. London: SAGE. https://doi.org/10.4324/9780203131725

National commission for human rights (2008) NHCR Annual report 2007 [in Greek]

Neary A. (2013) Lesbian and gay teachers' experiences of 'coming out' in Irish schools. British journal of sociology of education, 34(4), pp. 583-602. https://doi.org/10.1080/01425692.2012.722281 
Neary, A. (2017) Lesbian, gay and bisexual teachers' ambivalent relations with parents and students while entering into a civil partnership. Irish educational studies, 36(1), pp. 57-72. https://doi.org/10.1080/03323315.2017.1289702

Nias, J. (1996) Thinking about feeling: The emotions in teaching. Cambridge journal of education, 26(3), pp. 293-306. https://doi.org/10.1080/0305764960260301

Nixon, D. and Givens, N. (2004) "Miss, you're so gay." Queer stories from trainee teachers. Sex Education, 4(3), pp. 217-237. https://doi.org/10.1080/1468181042000243321

Oakley, A. (1981) Interviewing Women: A contradiction in terms. In: H. Roberts (ed) Doing Feminist Research, London: Routledge and Kegan Paul, pp. 30-61

Papadaki, V. and Papadaki, E. (2011) 'So, what about homosexuals?'-Views on homosexuality among social work students in Crete-Greece. European journal of social work, 14(2), pp. 265-280. https://doi.org/10.1080/13691451003744333

Papadaki, V., Plotnikof, K. and Papadaki, E. (2013) Social work students' attitudes towards lesbians and gay men: The case of the social work department in Crete, Greece. Social work education: The international journal, 32(4), pp. 453-467. https://doi.org/10.1080/02615479.2012.687371

\section{REMOVED FOR PEER REVIEW}

Pavlou, M. (2009) Homophobia in Greece: Love for equality. Athens: Institute for rights, equality and diversity

Phelan, S. (2001) Gays, lesbians, and dilemmas of citizenship. Philadelphia: Temple University Press

Racist Violence Recording Network (2016) Accessed from
http://rvrn.org/wpcontent/uploads/2016/04/Report_2015gr.pdf on 19/7/20016 [in Greek]

Reay, D. and Ball, S. (2000) Essentials of female management: Women's ways of working in the education marketplace? Educational management and administration, 28(2), pp 145-159. https://doi.org/10.1177/0263211X000282004

Rockhill, K. (1993) Dis/connecting literacy and sexuality: Speaking the unspeakable in the classroom. In Lankshear, C. and McLaren, P. L. (eds) Literacy: Politics, practice and the postmodern. New York: State University of New York Press, pp. 335-367

Rolfe, G. (2006) Validity, trustworthiness and rigour: Quality and the idea of qualitative research. Journal of advanced nursing, 53(3), pp. 304-310. https://doi.org/10.1111/j.13652648.2006.03727.x 
Rubin, H. and Rubin, I. (1995) Qualitative interviewing: The art of hearing data. Thousand Oaks: SAGE

Rush, T., Simonds, C. and Hunt, S. (2002) Coming Out in the Classroom... An Occupational Hazard?: The Influence of Sexual Orientation on Teacher Credibility and Perceived Student Learning. Communication education, 51(3), pp. 311-324. https://doi.org/10.1080/03634520216516

Stake, F. (2005) Qualitative case studies. In N. K. Denzin and Y. S. Lincoln (eds) The Sage handbook of qualitative research. Thousand Oaks: Sage, pp. 443-446

Taki, P. (2006) Women managing primary education. Unpublished PhD Thesis, Aristotle University of Thessaloniki [in Greek]

The Guardian (10/10/2017) Greece passes gender-change law opposed by Orthodox church. Accessed from https://www.theguardian.com/world/2017/oct/10/greece-passes-gender-changelaw on $\underline{20 / 10 / 2017}$

The Guardian (16/4/2014) Greece's Golden Dawn party describes Hitler as 'great personality'. Accessed from https://www.theguardian.com/world/2014/apr/16/greece-golden-dawn-hitler on $\underline{14 / 5 / 2014}$

Tzamalouka, G. (2000) Social representations of homosexuality in modern Greece. In Th. Papazizi, N. Chatzitrifon and Th. Ktenidis (eds) Gender and behaviour, homosexuality-homophobia. The situation in Greece and perspectives for improvement. 9-10 October, Thessaloniki. Conference Preceedings. Athens: Epikentro, pp. 133-144 [in Greek]

Tzamalouka, G. (2002) Social representations and attributional attitudes of homesexuality in modern Greece. Unpublished PhD thesis Panteion University: Faculty of Political and Social Sciences

Van Dijk, L. and van Driel, B. (2007) Challenging homophobia: Teaching about sexual diversity. Sterling: Trentham Books Ltd

Warner, M. (1993) Introduction. In M. Warner (ed) Fear of a queer planet: Queer politics and social theory. Minneapolis: university of Minessota Press, pp. vii-xxxi

West, C. and Zimmerman, D.H. (1987) Doing gender. Gender and Society, 1, pp. 125-151. https://doi.org/10.1177/0891243287001002002

Youdell, D. (2005) Sex-gender-sexuality: How sex, gender and sexuality constellations are constituted in secondary schools. Gender and education, 17(3), pp. 249-270. https://doi.org/10.1080/09540250500145148 